\title{
Evaluation of some pesticides against the tomato borer, Tuta absoluta (Meyrick) (Lepidoptera: Gelechiidae) under laboratory conditions
}

\author{
Mohanny K.M., G.S. Mohamed, R.O.H. Allam, and R.A. Ahmed* \\ Plant Protection Department, Faculty of Agriculture, South Valley University, Qena 83523, Egypt
}

\begin{abstract}
The tomato borer, Tuta absoluta (Meyrick) is considered a devastating pest, particularly to the tomato Lycopersicon esculentum. The present study was carried out to determine the efficacy of five pesticides namely, indoxacarb, (abamectin+ thiamethoxam), emamectin benzoate, fipronil and imidacloprid against the 3rd larval instar of $\mathrm{T}$. absoluta under laboratory conditions using the Leaf-dip method. The tested pesticides could be descendingly arranged as follows: emamectin benzoate, fipronil, (abamectin + thiamethoxam), indoxacarb and imidacloprid. The corresponding LC50 values after $72 \mathrm{~h}$. were 0.07, 0.22, 0.28, 0.59 and $2.67 \mathrm{ppm}$, while LC90 values were $0.56,3.25,1.99,4.69$ and $30.29 \mathrm{ppm}$, respectively. It is clear that emamectin benzoate was the most toxic compound, whereas imidacloprid was the least toxic one. Results indicated that emamectin benzoate can be used as a good element in integrated management program to this pest.
\end{abstract}

Keywords: Abamectin, Fipronil, Emamectin benzoate, Indoxacarb, Tomato, Tuta absoluta.

\section{Introduction}

The tomato borer, Tuta absoluta (Meyrick) is a Lepidopteran species of the family Gelechiidae it has assumed the status of the most important pest in Egypt. It has been reported in Egypt since 2009, quickly becoming one of the major pests of the tomato crop. T. absoluta is a multivoltine species that mines leaves, fruits, flowers, buds and stems. The damage is produced when the larvae feed on the leaf mesophyll expanding mines, thus affecting the photosynthetic capacity of the crop with

*Corresponding author: R.A. Ahmed

Email: raniaatefahmed75@gmail.com

Received: December 17, 2019;

Accepted: January 2, 2020;

Published: January 6, 2020. subsequent reduction of yield. Moreover, injury made directly to the fruits causes severe losses (Colomo and Berta, 2006). Larvae do not enter diapause when food is available and depending on the environmental conditions, so up to 12 generations per year may be able to develop (EPPO, 2005). Even though T. absoluta is an oligophagous pest with a strong preference for tomato (Notz, 1992) it can also attack other cultivated Solanaceae plants such as eggplant (Solanum melongena L.), potato (Solanum tuberosum), pepper (Capsicum annuum), sweet pepper (Solanum muricatum L.), tobacco (Nicotiana tabacum). Also, it infests Phaseolus vulgaris L. (bean) and Physalis peruviana L. (Cape gooseberry) (Desneux et al., 2010). 
Chemical Pesticides are one of the most common and widely used methods for controlling $T$. absoluta around the world because they have rapid action and strong toxicity against the target pest. Many researches has been done on using chemical pesticides for controlling T. absoluta

(Braham et al., 2012b.; Hafsi et al., 2012.; Deleva and Harizanova, 2014) with a great diversity of pesticide classes commonly used, such as carbamates, neonicotinoids, pyrethroids, avermectins, spinosyns, diamide and insect growth regulators (MAPA, 2017). The aim of this work was to evaluate different pestiticides against $T$. absoluta under laboratory conditions and to determine the effective dose for field application to succeed in controlling this pest under Upper Egypt conditions.

\section{Materials and Methods}

\section{Vegetable crop investigated}

Tomato plants Lycopersicon esculentum Mill Varity Super strain B Hybrid was cultivated in the farm of Faculty of Agriculture at South Valley University during (2017-2018) season.

\section{Insects}

Tuta absoluta larvae were collected from infested tomato plants from the farm of Faculty of Agriculture at South Valley University.

\section{Bioassey experiment}

Laboratory experiment was carried out to determine the effect of different pesticides under laboratory conditions using the Leafdip method. Five pesticides: indoxacarb, (abamectin + thiamethoxam), emamectin benzoate, fipronil and imidacloprid. Five concentrations of each tested pesticides were prepared. Fresh tomato leaflets were dipped in each prepared concentration of the tested pesticides for 10 seconds, control leaflets were dipped in water only (three replicates were used for each concentration), then the leaflets were left to dry. The dried leaflets were placed on a slightly moistened filter paper covering the bottom of petri dishes $(8$ $\mathrm{cm}$ diameter $\times 1.5 \mathrm{~cm}$ height). Ten $3^{\text {rd }}$ instar larvae of $T$. absoluta were carefully placed using a fine soft brush in each petri dishes and kept under laboratory conditions (IRAC, 2010).

Table 1. Pesticides used in the study

\begin{tabular}{|c|c|c|c|c|c|c|}
\hline No & Common name & Trade name & $\begin{array}{l}\text { Type of } \\
\text { Formulation }\end{array}$ & Conc. $\%$ & Rate/Fd & Chemical group \\
\hline 1 & $\begin{array}{l}\text { Abamectin + } \\
\text { Thiamethoxam }\end{array}$ & Gate Fast & $\mathrm{SC}$ & 12 & $200 \mathrm{ml}$ & $\begin{array}{l}\text { Avermectin }+ \\
\text { Neonicotinoid }\end{array}$ \\
\hline 2 & Fipronil & Coach & $\mathrm{SC}$ & $r$. & $50 \mathrm{ml}$ & Pyrazole \\
\hline 3 & Imidacloprid & Avenue & WG & $v \cdot$ & ${ }_{\mathrm{gm}}$ & Neonicotinoid \\
\hline 4 & Emamectin benzoate & Minoclem & WG & ० & $60 \mathrm{gm}$ & Avermectin \\
\hline 5 & Indoxacarb & Flax & $\mathrm{SC}$ & 10 & $50 \mathrm{ml}$ & Oxadiazine \\
\hline
\end{tabular}


Mortality was counted after 24, 48 and 72 hours. Larvae were considered as dead when they were not able to move back to the ventral position after being placed on their dorsum.

\section{Statistical analysis}

Data were considered acceptable if the mortalities observed in controls were less than $20 \%$. If there were mortalities in controls, data were adjusted using Abbot's formula (1925). Concentration-mortality regression lines were analyzed using a computer program modified from the method of Finney (1971) to estimate the $\mathrm{LC}_{50}$, the confidence limits and the slopes of LdP lines

\section{Results}

1. Toxicity of the tested pesticides against the $3^{\text {rd }}$ instar larvae of the tomato borer, $T$. absoluta under laboratory conditions

Data in Table (2) and Fig. (1) represented the relative toxicity of the toxic action of indoxacarb, (abamectin + thiamethoxam), emamectin benzoate, fipronil and imidacloprid against $3^{\text {rd }}$ instars larvae of $T$. absoluta by leaf dipping method at $24 \mathrm{~h}$. post treatment. Data clearly indicate that the tested pesticides could be descendingly arranged as follows: emamectin benzoate, fipronil, (abamectin + thiamethoxam), indoxacarb and imidacloprid. The corresponding $\mathrm{LC}_{50}$ values were $0.13,0.36$, 0.59, 0.94 and $3.93 \mathrm{ppm}$, while the $\mathrm{LC}_{90}$ values were $2.75,5.85,3.36,6.38$ and 40.82 ppm. On the other hand, $\chi^{2}$ values were 0.04 , $0.18,0.87,0.26$ and 0.53 respectively. Data in Table (2) show Toxicity of tested pesticides against the $3^{\text {rd }}$ instar larvae of $T$. absoluta after 24 hours it was observed that the toxicity index of emamectin benzoate, fipronil, (abamectin + thiamethoxam), indoxacarb and imidacloprid were 100, $36.11,22.03,13.82$, and $3.31 \%$ at the $\mathrm{LC}_{50}$ level, respectively.

Table 2. Toxicity of tested pesticides against the $3^{\text {rd }}$ instar larvae of T. absoluta after $24 \mathrm{~h}$.

\begin{tabular}{|c|c|c|c|c|c|c|c|}
\hline \multirow{2}{*}{ Pesticides } & \multirow{2}{*}{$\chi^{2}$} & \multirow{2}{*}{$\begin{array}{l}\mathrm{LC}_{50} \\
\mathrm{ppm}\end{array}$} & \multicolumn{2}{|c|}{$\begin{array}{l}\text { confidence limits } \\
\text { of } \mathrm{LC}_{50} \mathrm{ppm}\end{array}$} & \multirow{2}{*}{$\begin{array}{l}\mathrm{LC}_{90} \\
\mathrm{ppm}\end{array}$} & \multirow{2}{*}{ Slope $\pm \mathrm{SE}$} & \multirow{2}{*}{ T.I. } \\
\hline & & & Lower & Upper & & & \\
\hline Emamectin benzoate & 0.04 & 0.13 & 0.03 & 0.22 & 2.75 & $0.96 \pm 0.29$ & 100 \\
\hline Fipronil & 0.18 & 0.36 & 0.21 & 0.65 & 5.85 & $1.05 \pm 0.32$ & 36.11 \\
\hline Abamectin+Thiamethoxam & 0.87 & 0.59 & 0.39 & 0.8 & 3.36 & $1.69 \pm 0.29$ & 22.03 \\
\hline Indoxacarb & 0.26 & 0.94 & 0.63 & 2.38 & 6.38 & $1.54 \pm 0.38$ & 13.82 \\
\hline Imidacloprid & 0.53 & 3.93 & 2.08 & 22.68 & 40.82 & $1.26 \pm 0.33$ & 3.31 \\
\hline
\end{tabular}

$\chi^{2}=$ Chi-square $\quad$ T. I. = Toxicity Index (compared with Emamectin benzoate) 


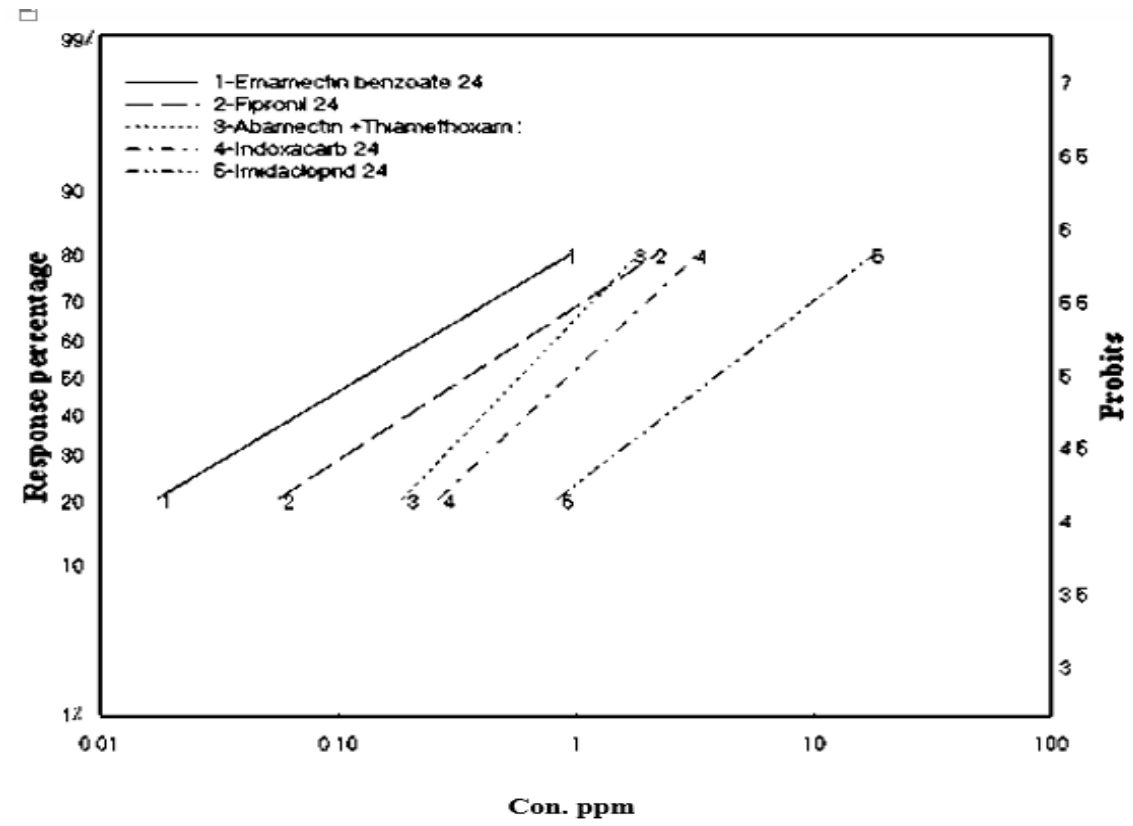

Figure 1. Toxicity of tested pesticides against the $3^{\text {rd }}$ instar larvae of T. absoluta after $24 \mathrm{~h}$.

Data in Table (3) and Fig. (2) represented the relative toxicity of the pesticides at $48 \mathrm{~h}$. after treatment. Data clearly indicate that the tested pesticides could be descendingly arranged as follows: emamectin benzoate, fipronil, (abamectin + thiamethoxam), indoxacarb and imidacloprid. The corresponding $\mathrm{LC}_{50}$ values were 0.09, 0.30, $0.43,0.74$ and $3.62 \mathrm{ppm}$, while the $\mathrm{LC}_{90}$ values were $1.22,5.13,3.32,6.60$ and 38.6 ppm. On the other hand, $\chi^{2}$ values were 0.01 , $0.38,2.09,0.17$ and 0.95 respectively. The toxicity index of emamectin benzoate, fipronil, (abamectin + thiamethoxam), indoxacarb and imidacloprid were 100, 30, 20.93, 12.16 and $2.48 \%$ at the $\mathrm{LC}_{50}$ level, respectively. As shown in Table (3) emamectin benzoate was the most toxic compound against larvae of $T$. absoluta the difference between the values of $\mathrm{LC}_{50}$ was significant. Data in Table (4) and Fig. (3) Represented the relative toxicity of the toxic action of the pesticides at $72 \mathrm{~h}$. after treatment. Data clearly indicate that the tested pesticides could be descendingly arranged as follows: emamectin benzoate, fipronil, (abamectin + thiamethoxam), indoxacarb and imidacloprid.

The corresponding $\mathrm{LC}_{50}$ values were 0.07 , $0.22,0.28,0.59$ and $2.67 \mathrm{ppm}$, while the $\mathrm{LC}_{90}$ values were $0.56,3.25,1.99,4.69$ and $30.29 \mathrm{ppm}$. On the other hand, $\chi^{2}$ values were $0.13,0.32,0.27,0.52$ and 0.37 respectively. Data in Table (4) show that the toxicity index of emamectin benzoate, fipronil, (abamectin + thiamethoxam), indoxacarb and imidacloprid were 100, $31.82,25,11.86$ and $2.62 \%$ at the $\mathrm{LC}_{50}$ level, respectively. As shown in Table (4) emamectin benzoate was the most toxic compound against larvae of $T$. absoluta the difference between the values of $\mathrm{LC}_{50}$ was significant. 
Table 3. Toxicity of tested pesticides against the $3^{\text {rd }}$ instar larvae of T. absoluta after $48 \mathrm{~h}$.

\begin{tabular}{|c|c|c|c|c|c|c|c|}
\hline \multirow[t]{2}{*}{ Pesticides } & \multirow[t]{2}{*}{$\chi^{2}$} & \multirow[t]{2}{*}{$\begin{array}{l}\mathrm{LC}_{50} \\
\mathrm{ppm}\end{array}$} & \multicolumn{2}{|c|}{$\begin{array}{l}\text { confidence } \\
\text { limits of LC } 50 \\
\text { ppm }\end{array}$} & \multirow[t]{2}{*}{$\begin{array}{c}\mathrm{LC}_{90} \\
\mathrm{ppm}\end{array}$} & \multirow[t]{2}{*}{ Slope \pm SE } & \multirow[t]{2}{*}{ T.I. } \\
\hline & & & Lower & Upper & & & \\
\hline Emamectin benzoate & 0.01 & 0.09 & 0.02 & 0.16 & 1.21 & $1.13 \pm 0.32$ & 100 \\
\hline Fipronil & 0.38 & 0.30 & 0.16 & 0.51 & 5.13 & $1.04 \pm 0.32$ & 30 \\
\hline Abamectin+Thiamethoxam & 2.09 & 0.43 & 0.24 & 0.63 & 3.32 & $1.45 \pm 0.29$ & 20.93 \\
\hline Indoxacarb & 0.17 & 0.74 & 0.49 & 1.81 & 6.60 & $1.35 \pm 0.35$ & 12.16 \\
\hline Imidacloprid & 0.95 & 3.62 & 1.95 & 18.92 & 38.6 & $1.25 \pm 0.33$ & 2.48 \\
\hline
\end{tabular}

$\chi^{2}=$ Chi-square $\quad$ T. I. = Toxicity Index (compared with Emamectin benzoate)

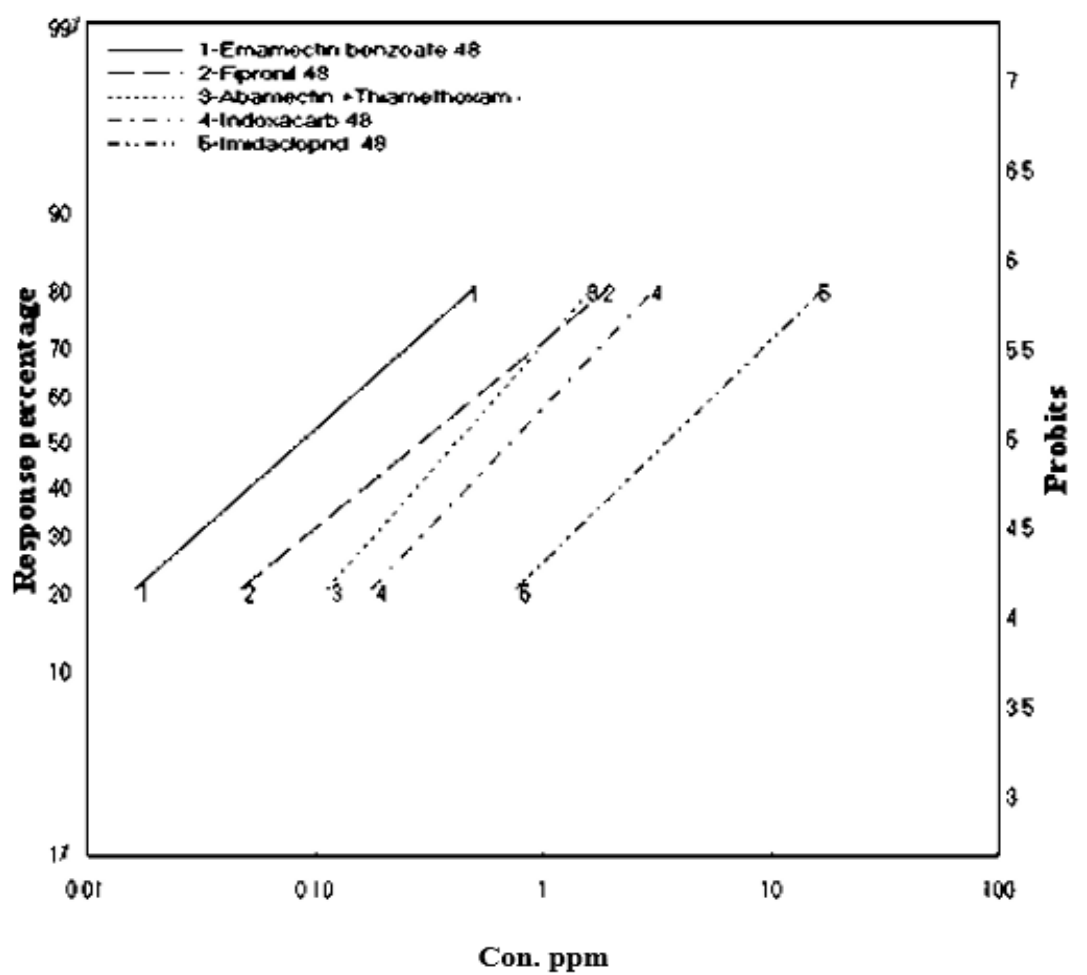

Figure 2. Toxicity of tested pesticides against the $3^{\text {rd }}$ instar larvae of T. absoluta after $48 \mathrm{~h}$. 
Table 4. Toxicity of tested pesticides against the $3^{\text {rd }}$ instar larvae of T. absoluta after $72 \mathrm{~h}$.

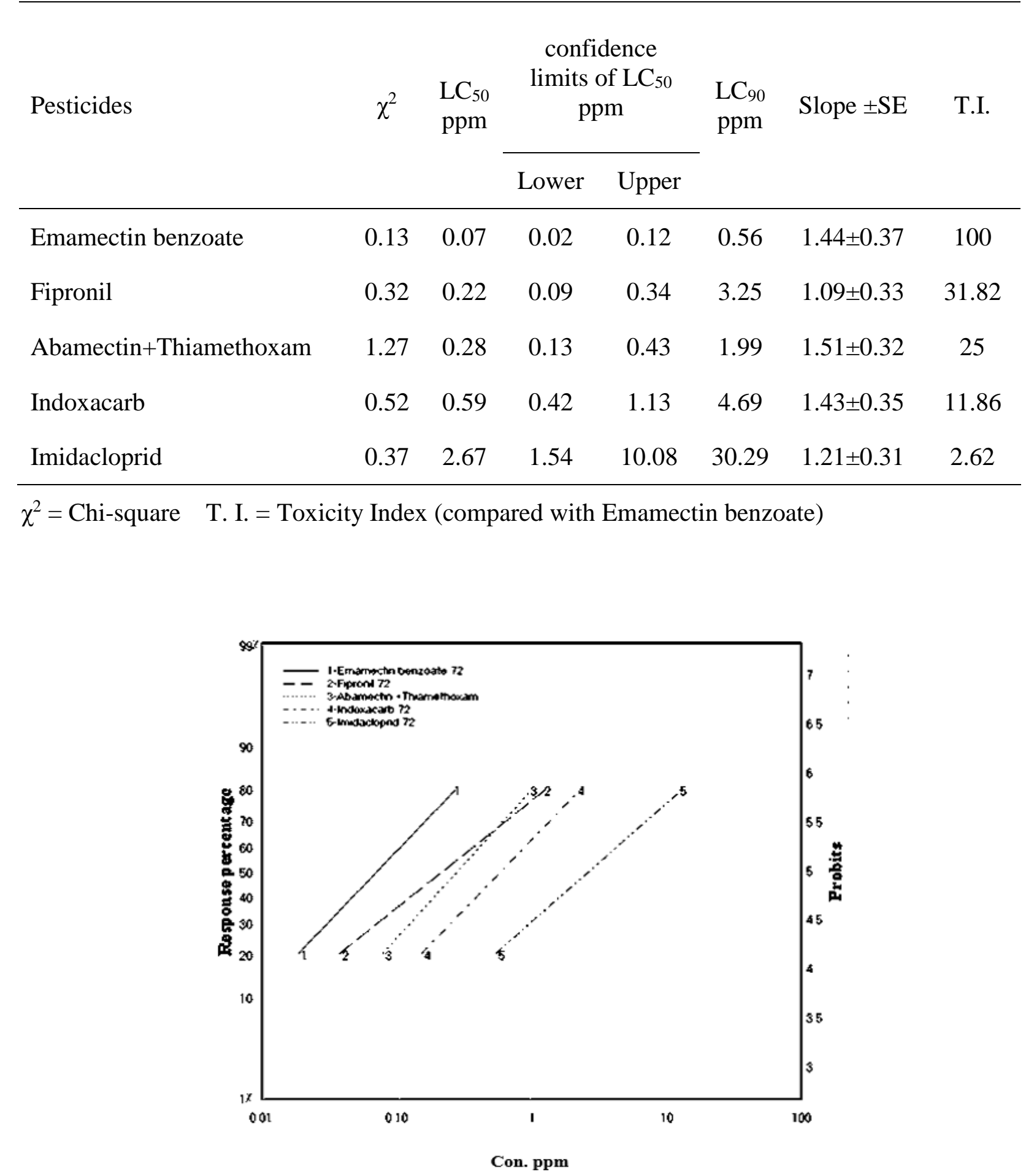

Figure 3. Toxicity of tested pesticides against the $3^{\text {rd }}$ instar larvae of T. absoluta after $72 \mathrm{~h}$. 


\section{Discussion}

The effect of all five pesticides has increased and reached the highest after $72 \mathrm{~h}$. after the bioassay. It is obvious, as shown in Tables (2), (3), (4) and Fig. (1), (2), (3) that emamectin benzoate had the steepest toxicity line and imidacloprid had the flattest, however fipronil, (abamectin + thiamethoxam), indoxacarb lie in between; this reflects the superiority of emamectin benzoate and inferiority of imidacloprid. These results were in agreement with those of Braham and Hajji (2012a) who showed that emamectin benzoate confirmed its effectiveness in populations of $T$. absoluta in laboratory. Bala et al. (2019) found that the highest susceptibility was observed from abamectin with mortality of $86 \%$ and $\mathrm{LD}_{50}$ of 0.034 ppm. Roditakis et al. (2013) estimated the toxicity of some insecticides registered for $T$. absoluta control namely, flubendiamide, chlorantraniliprole, emamectin benzoate, spinosad, metaflumizone, indoxacarb , chlorpyriphos and cypermethrin. The results showed that Low heterogeneity was detected in the populations tested with most insecticides. The $\mathrm{LC}_{50}$ values ranged from 0.31 to 1.31 $\mathrm{mg} / \mathrm{L}$ for flubendiamide, from 0.12 to 0.53 $\mathrm{mg} / \mathrm{L}$ for chlorantraniliprole, from 0.03 to $0.12 \mathrm{mg} / \mathrm{L}$ for emamectin benzoate, from 0.08 to $0.26 \mathrm{mg} / \mathrm{L}$ for spinosad, from 31.8 to $159.5 \mathrm{mg} / \mathrm{L}$ for metaflumizone, from 1.73 to $17.5 \mathrm{mg} / \mathrm{L}$ for indoxacarb, from 530 to $2038 \mathrm{mg} / \mathrm{L}$ for chlorpyriphos and finally from 475 to $794 \mathrm{mg} / \mathrm{L}$ for cypermethrin. Shalaby et al. (2012) showed that cyfluthrin, profenofos chlorpyriphos-methyl lufenuron, and indoxacarb were the most toxic insecticides as compared to other chemicals against tomato leaf miner, T. absoluta under the laboratory conditions. Gacemi et al. (2016) studied the effectiveness of two biopesticide, emamectin benzoate and spinosad against larval stages of $T$. absoluta under laboratory conditions. Their results showed that the emamectin benzoate and spinosad were very effective on larvae of T.absoluta. The emamectin benzoate caused complete mortality of treated larvae. Gacemi and Guenaoui (2012) conducted greenhouse experiments to demonstrate the effect of emamectin benzoate on $T$. absoluta; the results showed very significant effect of emamectin benzoate against larvae of this pest. Abdel-Baky et al. (2019) evaluated the efficacy of emamectin benzoate insecticide against $T$. absoluta under laboratory conditions its results indicated that emamectin benzoate was effective against larval stages of $T$. absoluta under laboratory conditions and caused a significant percentage mortality after 24 hours of treatment and the percentage of mortality increased gradually with time. Abdelgaleil et al. (2015) determined the effectiveness of four insecticides, abamectin + thiamethoxam, chlorpyrifos, spinosad and imidacloprid in controlling T. absoluta and he found that imidacloprid was the least effective one.

\section{Conclusions}

The evaluation of tested pesticides showed that emamectin benzoate was the most toxic compound, whereas imidacloprid was the least toxic one against Tuta absoluta (Meyrick). Therefore, it was recommended that emamectin benzoate can be used as an element in integrated pest management of 
Tuta absoluta (Meyrick) under Upper Egypt conditions.

\section{Acknowledgements}

This study was kindly sponsored by the Plant Protection Department, Faculty of agriculture, South Valley University, Qena, Egypt.

\section{References}

Abbott, W.S. (1925) 'A method of computing the effectiveness of an insecticide', J. econ. Entomol, 18(2), pp. 265-267. doi: 10.1093/jee/18.2.265a

Abdel-Baky, N.F., Alhewairini, S.S., Bakry, M. (2019) 'Emamectin-benzoate against Tuta absoluta Meyrick and Spodoptera littoralis Boisduval larvae', Pakistan Journal of Agricultural Sciences, 56(3), pp.801-808.

doi: 10.21162/PAKJAS/19.8082

Abdelgaleil, S. A., El-Bakary, A. S., Shawir, M. S., Ramadan, G. R. (2015) 'Efficacy of various insecticides against tomato leaf miner, Tuta absoluta, in Egypt', Applied Biological Research, 17(3), pp. 297-301. doi:10.5958/09744517.2015.00042.7

Bala, I., Mukhtar, M., Saka, H., Abdullahi, N., Ibrahim, S. (2019) 'Determination of Insecticide Susceptibility of Field Populations of Tomato Leaf Miner (Tuta absoluta) in Northern Nigeria', Agriculture, 9(7), pp.1-13. doi: 10.3390/agriculture9010007

Braham, M., Glida-Gnidez, H., Hajji, L. (2012b) 'Management of the tomato borer, Tuta absoluta in Tunisia with novel insecticides and plant extracts',
EPPO bulletin, 42(2), pp. 291-296. doi: 10.1111/epp. 2572

Braham, M., Hajji, L. (February 15th 2012a) 'Management of Tuta absoluta (Lepidoptera, Gelechiidae) with insecticides on tomatoes', in Farzana Perveen (Ed.). Insecticides-Pest Engineering. IntechOpen, pp. 333-354. doi: $10.5772 / 27812$

Colomo, M.V., Berta, D.C. (2006) 'First record of a member of the Exoristini (Diptera, Tachinidae) in Tuta absoluta (Lepidoptera, Gelechiidae)', Acta Zoologica Lilloanna, 50(1/2), pp. 123124.

Deleva, E.A., Harizanova, V.B. (2014) 'Efficacy evaluation of insecticides on larvae of the tomato borer Tuta absoluta, Meyrick (Lepidoptera: Gelechiidae) under laboratory conditions', Agriculture and Food, 2(1), pp. 158-164.

Desneux, N., Wajnberg, E., Wyckhuys, K. A., Burgio, G., Arpaia, S., NarváezVasquez, C.A., Pizzol, J. (2010) 'Biological invasion of European tomato crops by Tuta absoluta: ecology, geographic expansion and prospects for biological control', Journal of pest science, 83(3), pp. 197-215. doi: 10.1007/s10340-010-0321-6

EPPO. (2005) 'European and Mediterranean Plant Protection Organization. Tuta absoluta. Data sheets on quarantine pests', EPPO Bulletin, 35, pp. 434-435. doi: 10.1111/j.1365-2338.2005.00852.x

Finney, D. J. (1971) 'Probit analysis', Cambridge University Press. Cambridge, UK. 
Gacemi, A., Bensaad, R., Guenaoui, Y. (2016) 'Effect of Biopesticides Spinosad and Emamectin on Developmental Stages of the Tomato Leafminer Tuta absoluta Meyrick (Lepidoptera: Gelechiidae)', Academic Journal of Entomology, 9(1), pp. 08-13. doi:10.5829/idosi.aje.2016.9.1.10253

Gacemi, A., Guenaoui, Y. (2012) 'Efficacy of emamectin benzoate on Tuta absoluta Meyrick (Lepidoptera: Gelechiidae) infesting a protected tomato crop in Algeria', Academic Journal of Entomology, 5(1), pp. 37-40 doi: 10.5829/idosi.aje.2012.5.1.6315

Hafsi, A., Abbes, K., Chermiti, B., Nasraoui, B. (2012) 'Response of the tomato miner Tuta absoluta (Lepidoptera: Gelechiidae) to thirteen insecticides in semi-natural conditions in Tunisia', EPPO bulletin, 42(2), pp. 312-316. doi: 10.1111/epp. 2575

IRAC. (2010) 'Insecticide Resistance Action Committee', Susceptibility test methods series.

MAPA. (2017) 'Ministério da Agricultura, Pecuáriae Abastecimento. Brazil', http://agrofit.agricultura.gov.br/agrofit_ cons/principal_agrofit_cons (Accessed: 23 September).

Notz, A.P. (1992) 'Distribution of eggs and larvae of Scrobipalpula absoluta in potato plants', Revista de la Facultad de Agronomía (Maracay), 18, pp. 425432.

Roditakis, E., Skarmoutsou, C., Staurakaki, M. (2013) 'Toxicity of insecticides to populations of tomato borer Tuta absoluta (Meyrick) from Greece', Pest
Management Science, 69(7), pp. 83484. doi: $10.1002 / p s .3442$

Shalaby, S. E., Soliman, M. M., Ei-Mageed, A. E. M. A. (2012) 'Evaluation of some insecticides against tomato leaf minor (Tuta absoluta) and determination of their residues in tomato fruits', Applied Biological Research, 14(2), pp. 113119. 